\title{
Sweden's Collective Defence Obligations or this is Not a Collective Defence Pact (or Is It?): Considerations of International and Constitutional
}

\section{Law}

\author{
Inger Österdahl \\ Professor in Public International Law, Uppsala University, Uppsala, Sweden \\ Inger.Osterdahl@jur.uu.se
}

\begin{abstract}
This article analyses the content of the mutual defence obligation contained in the EU Treaty Article 42(7) in relation to the Swedish constitutional rule on the sending of armed forces abroad and the emerging 'deepened defence cooperation' between Sweden and Finland. The article tries to understand the prevailing Swedish position in legal terms and suggests an alternative flexible way on Sweden's part of conceiving the binding force of Article 42(7). The question is whether the EU Treaty contains an international obligation of a quality to activate a provision in the Swedish Constitution entitling the government to decide on its own, without having to seek the otherwise necessary approval by Parliament, to send Swedish armed forces to other countries for instance on a mission of collective self-defence. The possibility of looking at the EU Treaty and the Swedish Instrument of Government in this way is not considered in any of the Swedish official inquiries into the Swedish security and defence policy of which there have been quite a few recently.
\end{abstract}

\section{Keywords}

collective self-defence - unilateral declaration - binding - non-alignment international law and domestic law 
To be nor not to be party to a mutual defence clause, that is the question. What is in a mutual defence clause is another question, and what is in an international obligation?

This article takes as its starting point the existence of the mutual defence clause in Article 42(7) of the Treaty on European Union (TEU) to which Sweden is a party. As a non-aligned state Sweden however claims that it is not bound by the mutual defence clause. A 'deepened defence cooperation' is also developing between Sweden and Finland which closely resembles what would otherwise be labelled an agreement on mutual defence. However, in this case it is not legally binding in form, and it is never referred to as a collective defence pact. Sweden maintains that it is under no obligation to intervene in the defence of any other country.

The article asks how it can be that Sweden is party to an international agreement including a mutual defence clause and simultaneously claims that it not legally bound by the mutual defence clause. The article investigates the arguments used and evaluates the arguments from a legal point of view. The article tries to understand, or make sense of, the Swedish position from the point of view of the law. Is it possible simultaneously to be bound and not to be bound by a treaty article? If Sweden is not bound, is Sweden still entitled to assistance under the mutual defence clause in case of need?

The article also asks what are the Swedish constitutional rules regulating the potential exercise of Swedish individual and collective self-defence and whether it would be possible under the current Constitution to apply the same decision-making procedure in the case of collective as in the case of individual self-defence operations. The crucial issue is whether there is a basis in the Swedish Instrument of Government for leaving it to the government alone to decide also on collective self-defence measures, as in the case of individual self-defence, or whether the Parliament must always be included in the decision-making on collective self-defence with the prolonged period of time that this will require before a decision can be arrived at. An alternative to the conventional way of interpreting the constitutional rules is suggested in the article.

The article also discusses the difference in practice of Sweden being legally bound and not being legally bound by mutual defence obligations in relation to the EU members and more particularly in relation to Finland. With the exception of a possible speeding up of the internal Swedish decision-making in the case of collective self-defence, which a binding international obligation would provide conditions for, the difference in practice would most likely be insignificant. This is supported by the Swedish unilateral 'declaration of solidarity' with respect to all the members of the EU, and Norway and Iceland. 
Sweden is likely to fulfil its obligations towards the EU members including Finland regardless of whether the obligations are legal or non-legal or binding or non-binding. If Sweden had no intention of fulfilling its defence obligations of whatever normative quality toward the EU members and Norway and Iceland then any deepened defence cooperation not to speak of the 'declaration of solidarity' would be pointless in the first place. The deterring effect of the defence cooperation on any potential aggressor would disappear entirely. It must be presumed further that Finland in particular counts on Sweden fulfilling its (non-legal) obligations toward Finland, and vice versa. Thus, Sweden can claim that it is not bound by any defence obligations and simultaneously intend to fulfil every thinkable - however, not legally binding - obligation it may have.

Against this background this article sets out to answer the following questions. Is Article 42(7) a binding agreement on collective self-defence? Is Sweden bound by Article 42(7)? What difference would it make for the Swedish constitutional decision-making procedure whether Sweden is bound by Article 42(7) in the TEU or not? And, in practice, what difference would it make whether Sweden is party to a collective defence agreement or not?

\section{The International Legal Framework}

\subsection{The EUMutual Defence Clause}

In 2007 a mutual defence clause was inserted into the TEU. Article 42(7) of the TEU lays down that:

If a Member State is the victim of armed aggression on its territory, the other Member States shall have towards it an obligation of aid and assistance by all the means in their power, in accordance with Article $5^{1}$ of the United Nations Charter. This shall not prejudice the specific character of the security and defence policy of certain Member States.

Commitments and cooperation in this area shall be consistent with commitments under the North Atlantic Treaty Organisation, which, for those States who are members of it, remains the foundation of their collective defence and the forum for its implementation.

According to this author, for all practical purposes, the formulation of the first paragraph of Article 42(7) looks like a conventional collective defence undertaking. ${ }^{1}$ Further, according to this author, the reference to different

The clause can be traced back to the Treaty on Economic, Social and Cultural Collaboration and Collective Self-Defence (emphasis added) (The Brussels Treaty) of 17 March 1948, Article IV. Through the Paris Agreements of 23 October 1954, creating the 
states' different security and defence policies does not alter this impression nor does it detract from the legal force of the clause. ${ }^{2}$ This view corresponds to the Finnish view put forward in the Finnish government bill to Parliament of 2016

Western European Union, a reference to NATO preceding the mutual defence clause was inserted into the Brussels Treaty in Article IV and Article IV was renumbered Article V. Views differ considerably on the matter of whether or not Article 42(7) constitutes an agreement on collective defence. For the view that it does, see for instance K. Devine, 'Neutrality and the development of the European Union's common security and defence policy: Compatible or competing?' 46:3 Cooperation and Conflict (2011) pp. 334-369, p. 355 and the sources cited therein; T. Dyson and T. Konstantinides, European Defence Cooperation in EU Law and IR Theory (Palgrave MacMillan, Houndmills, Basingstoke; New York, NY, 2013 p. 67 et seq.; B. Hugemark and J. Tunberger, Trovärdig solidaritet? Försvaret och solidaritetsförklaringen (Trustworthy solidarity? The defence and the declaration of solidarity, (Stiftelsen Den Nya Välfärden, Bromma, 2010) <www.dnv.se/wp-content/ upioads/2013/og/Fvrsvarsbok_lowres.pdf $>$, visited on 20 August 2020. For the view that it does not, see for instance P. Koutrakos, 'The role of law in Common Security and Defence Policy: functions, limitations and perceptions', in P. Koutrakos (ed.), European Foreign Policy: Legal and Political Perspectives (Edward Elgar, Cheltenham; Northampton, MA, 2011) pp. 235-258, pp. 238-239; P.J. Kuijper, J. Wouters, F. Hoffmeister, G. De Baere, and T. Ramopoulos, The Law of EU External Relations: Cases, Materials, and Commentary on the EU as an International Legal Actor (Oxford, Oxford University Press, 2016) p. 690. For the view that it probably might, see for instance B. Van Vooren and R. A. Wessel, $E U$ External Relations Law: Text, Cases and Materials (Cambridge, Cambridge University Press, 2014) p. 404; F. Naert, International Law Aspects of the EU's Security and Defence Policy, with a particular focus on the law of armed conflict and human rights (Antwerp; Oxford; Portland, Intersentia, 2010) pp. 227-233. The author wishes to thank the Torsten Söderberg Foundation for making the writing of this article possible through grant number R5/17 Krigets juridik i den svenska regeringsformen: ett rörligt mål (The law of war in the Swedish Instrument of Government: a moving target). The author also would like to thank the anonymous reviewer for constructive criticism. All translations into English are the author's own except where otherwise pointed out.

Views differ on whether the so-called neutral EU members are exempted from the mutual assistance obligation or not. Van Vooren and Wessel, supra note 1, p. 404, think they are. M. Reichard, The EU-NATO Relationship. A Legal and Political Perspective (Aldershot, Hampshire; Burlington, VT, 2006) pp. 211, 213, 223 thinks they are; M. Reichard draws the further conclusion that the neutral EU members "are not bound by the mutual defence clause, and cannot as of right call for help from other member States in case of an attack on them"(p. 213), and further, the neutral states "do not benefit from the mutual defence guarantee" (in what later became TEU Article 42(7)) (p. 223). Naert, supra note 1, p. 233, after some deliberation eventually seems to land in a compromise opinion about what the mutual defence clause in TEU Article 42(7) amounts to: "a mutual defence clause in which all Member States, including the present neutrals, will participate but which will not cover the implementation of this clause." Perhaps S. Graf von Kielmansegg, 'The European Union's competences in defence policy - scope and limits', 32:2 European Law Review (2007) pp. 213-231, p. 231 also approaches a compromise formula in saying that the mutual defence clause in what became Article 42(7) in the TEU, "would mean a departure 
containing a proposed Act on the Provision and Reception of International Assistance: ${ }^{3}$

The mutual defence clause is equally binding on all member states. It addresses all member states in the same way. The references to the special position of certain member states or to commitments made within the North Atlantic Treaty Organization which have been attached to the mutual defence clause do not exempt the member states in question from participating in the implementation of the clause. The references to the particular position of certain member states or to the role of NATO do not deprive any of the member states of the right to assistance according to the provision. ${ }^{4}$

In comparison, Article 5 in the North Atlantic Treaty Organization (NATO) treaty laying down the collective defence obligation between the members of NATO runs like this:

The Parties agree that an armed attack against one or more of them in Europe or North America shall be considered an attack against all and consequently they agree that, if such an armed attack occurs, each of them, in exercise of the right of individual or collective self-defence recognized by Article 51 of the Charter of the United Nations, will assist the Party or Parties so attacked by taking forthwith, individually and in concert with the other Parties, such action as it deems necessary, including the use of armed force, to restore and maintain the security of the North Atlantic area (emphasis added).

from the principle of voluntariness and, thus, a first step into the realm of common defence (emphasis added)."; O. Bring, En folkrättslig tolkning av solidaritetsklausulerna: Säkerhetspolitiskt och försvarspolitiskt samarbete som en internationell förpliktelse (An international legal interpretation of the solidarity clauses: Security policy and defence policy cooperation as an international obligation), Bilaga 2 (Annex 2), Försvarspolitiskt samarbete - effektivitet, solidaritet, suveränitet (Defence policy cooperation - efficiency, solidarity, sovereignty), Fö 2013:B, pp. 81-89, pp. 82, 88 thinks the neutral states are not exempted from the mutual assistance obligation in TEU Article 42(7); neither does Devine, supra note 1, p. 355; Hugemark and Tunberger, supra note 1, p. 22 consider that an exception is made in Article 42(7) for neutral or non-aligned states, but that Sweden through its unilateral 'declaration of solidarity' has established that no such exception applies to Sweden.

3 Regeringens proposition (Government bill) RP 72/2016 rd, 4 May 2016, Section 2 Current situation, Sub-section 2.2 The international development and EU law, Sub-section 2.2.1 The Lisbon treaty clauses. Ibid. 
Judging from the mere wording of the respective collective defence clauses, the content of the respective commitments is the same, according to this author, or put differently nothing in the wording of the two clauses would suggest that their respective meanings would be very different except their different geographical reach. ${ }^{5}$

Thus judging only from the text of Article 42(7) in the TEU, the collective defence obligation between the EU members is equivalent to the collective defence obligation between the members of NATO; if anything, Article 42(7) places higher demands on the parties than does Article 5 of the NATO treaty. ${ }^{6}$

Article 42(7) has been invoked once so far in the wake of the terror attacks in Paris in November 2015. ${ }^{7}$ France invoked Article 42(7), and all the member states of the EU promised that they were prepared to aid and assist France, which some of them subsequently did on a bilateral basis and among them Sweden.

In two Swedish Government Official Reports, of 2016 and 2018 respectively, relating to the Swedish defence cooperation with Finland, the collective defence clause in the TEU to which Sweden as well as Finland is a party is not mentioned. ${ }^{8}$ In both Government Official Reports, of 2016 and 2018, it is explicitly stated that today no international obligation exists for Sweden requiring that a Swedish armed force is deployed or sent abroad. ${ }^{9}$ Likewise, in

Views differ on whether or not Article 5 in the NATO Treaty and Article 42(7) in the TEU are comparable Koutrakos, supra note 1, p. 239 thinks they are not; neither does Naert, supra note 1, p. 230; Van Vooren and Wessel, supra note 1, p. 404 think the clauses are comparable; so does Bring, supra note 2, p. 83; Dyson and Konstantinides, supra note 1, pp. 67-68 think they are comparable ("the 'EU version' of Article 5 of the Washington Treaty"); so do Hugemark and Tunberger, supra note 1, p. 22; and so does Ahlin, Efter neutralitetspolitiken: Folkrätten i svensk säkerhetspolitik 1993-2017 (International law in Swedish security policy 1993-2017) (Jure förlag, Stockholm, 2018) p. 44.

The TEU Article 42(7) states that "the other Member States shall have towards [the attacked Member State] an obligation of aid and assistance by all the means in their power ..." (emphasis added), whereas the NATo Treaty Article 5 lays down that "if ... an armed attack occurs, each of [the Parties] ... will assist the Party or Parties so attacked by taking forthwith ... such action as it deems necessary, including the use of armed force ...." Cf. also S. Blockmans and P. Koutrakos, Research Handbook on the EU's Common Foreign and Security Policy (Edward Elgar Publishing, Cheltenham; Northampton, MA, 2018) pp. 158.

Council of the EU, 14120/5, Outcome of the Council Meeting, 3426th Council Meeting, Foreign Affairs, Brussels, 16 to 17 November 2015 .

Förutsättningar enligt regeringsformen för fördjupat försvarssamarbete (Conditions under the Instrument of Government for deepened defence cooperation) Statens Offentliga Utredningar (sOu) (Swedish Government Official Reports series) 2016:64; En lag om operativt militärt stöd mellan Sverige och Finland (A law on operational military support between Sweden and Finland) sou 2018:31.

9 SOU 2016:64, supra note 8, p. 106; sou 2018:31, supra note 8, p. 83. 
the recent government bill to Parliament of 2020 on operational military support between Sweden and Finland, it is stated that no international obligation exists requiring Sweden to deploy its armed forces. ${ }^{10}$

The discussion in the Government Official Report of 2016, which dealt with the Swedish constitutional conditions for deepened defence cooperation with Finland, is caused by the fact that in the Swedish Instrument of Government it is laid down in Chapter 15, Article 16 (hereinafter Article 15:16) that one of the instances in which the government may send Swedish armed forces to other countries or otherwise deploy such forces is in order to fulfil an international obligation approved by the Parliament. If such an international obligation exists, the government may decide to send Swedish armed forces abroad without having to consult Parliament in the particular case.

If the Swedish Parliament would approve an agreement between Sweden and another state or organisation, the Government Official Report states further, which would entail an obligation for Sweden to deploy or send Swedish armed forces to another country under certain circumstances, the provision in Article 15:16 thus permits that the government decides on the deployment or sending of the armed forces in the individual case. ${ }^{11}$ If the government is allowed to make the decision on its own to send armed forces abroad in order for instance to assist Finland in the latter's self-defence against an armed attack, the decision could be reached faster than if the government would have to involve Parliament in the decision-making. The speed with which decisions can be made in the potential mutual collective defence operations of Sweden and Finland is a major concern when the need for new legislation caused by the deepened defence cooperation between the two countries is considered. ${ }^{12}$ The Government Official Report of 2016 adds that the provision in Article 15:16 does not contain any limitation of the purposes for which or in what situations Swedish armed forces may be deployed or sent abroad. ${ }^{13}$

Regeringens proposition (government bill) 2019/20:110 Operativt militärt stöd mellan Sverige och Finland (Operational military support between Sweden and Finland) 5 March 2020, pp. 14-15 (The Law on operational military support between Sweden and Finland was adopted by the Swedish parliament on 8 September 2020 and entered into force on 15 October 2020 (Svensk författningssamling (Collection of Swedish statutes) (SFS) 2020:782); see also the bill presented by the government to parliament at the time of the ratification of the Lisbon agreement: "It is the view of the government ... that [Article $42(7)$ ] does not involve any forms of defence obligations for non-aligned member states like Sweden." (regeringens proposition (government bill) 2007/08:168 Lissabonfördraget (The Lisbon Treaty), 3 July 2008, p. 252).

11 SOU 2016:64, supra note 8, p. 107.

12 Cf. sou 2018:31, supra note 8, chapter 4 pp. 59-78.

13 SOU 2016:64, supra note 8, p. 107. 


\title{
Comparing with Agreements on Collective Security under the UN Charter
}

The provision on an international obligation as one of several possible bases under the Swedish Constitution for sending armed forces abroad, or otherwise deploying such forces, was originally introduced in order to enable the government to send armed forces abroad in the cases intended in Article 43 of the UN Charter. ${ }^{14}$ The provision is not limited to the case of the UN, however, the Government Official Report of 2016 adds. ${ }^{15}$

Article 43 of the UN Charter, which so far has never been applied, lays down that:

\begin{abstract}
All Members of the United Nations, in order to contribute to the maintenance of international peace and security, undertake to make available to the Security Council, on its call and in accordance with a special agreement or agreements, armed forces, assistance, and facilities, including rights of passage, necessary for the purpose of maintaining international peace and security.
\end{abstract}

True, the intention of the provision in the UN Charter is different from the intention behind the collective defence provision in the TEU; the latter for instance is a collective defence clause whereas the former is a collective security clause. However, the difference in actual fact as to the intended effects of the respective provisions would not seem to be that great. In addition, the provision on the fulfilment of an international obligation in the Swedish Instrument of Government Article 15:16 is not limited to situations involving the UN and, moreover, as mentioned above, the provision contains no limitations of the purposes or situations in which Swedish armed forces may be sent abroad. ${ }^{16}$

It must be presumed, furthermore, that even though there would be agreements already concluded between the UN and the troop contributing country concerned, Sweden in our case, and the Swedish government consequently under the Swedish Instrument of Government Article 15:16 would be entitled

SOU 2016:64, supra note 8, pp. 106-107; cf. also Sveriges statsskick (The constitution of Sweden), sou 1963:17, p. 478; Ny regeringsform,ny riksdagsordning (New Instrument of Government, new Riksdag Act), sou 1972:15, pp. 189-19o; regeringens proposition (government bill) 1973:9o Förslag till ny regeringsform och ny riksdagsordning $\mathrm{mm}$. (Proposal for a new Instrument of Government and a new Riksdag Act, and more), 16 March 1973, p. 374. 
to make the decision on its own to make Swedish armed forces available to the Security Council, there would always remain a measure of freedom on the part of Sweden either to respond positively to the call of the Security Council, or not, in every (potential) particular case. The call by the Security Council thus would not be automatically favourably answered every time it was potentially made but the Swedish government would ultimately decide independently in every case whether to make Swedish armed forces available to the Security Council or not.

\subsection{Article 42(7) as an International Obligation}

Since according to the Swedish Government Official Report of 2018 proposing a law on operative military support between Sweden and Finland "there is no international obligation requiring that Sweden sends armed forces to Finland in support of Finland", the Government Official Report considers that the Swedish Parliament must adopt a law stating under what conditions the government may decide to send armed forces to Finland, in order to speed up the subsequent (potential) decision-making in each case. ${ }^{17}$ In accordance with Article 15:16 in the Swedish Instrument of Government, in addition to the situation where there exists an international obligation approved by Parliament, the government may send Swedish armed forces to other countries if it is permitted by an act of law setting out the conditions for such action.

As a comparison, Finland has adopted a law in 2017 - Act on the Provision and Reception of International Assistance - stating that the Finnish defence forces may assist another state, the European Union or an international organisation. ${ }^{18}$ The Finnish law also lays down that Finland may request assistance from the same entities. ${ }^{19}$ The Finnish law further refers explicitly to Article $42(7)$ of the TEU, as well as to Article 222 of the TFEU, as a basis for the granting of or request for such assistance. ${ }^{20}$

17 SOU 2018:31, supra note 8, p. 83 .

18 Act 418/2017 on the Provision and Reception of International Assistance, 28 June 2017, Article 1; cf. also H. Tuuri, 'Finland's Changing Stance on Armed Measures: How Does it Correspond to International Law?', 87:2 Nordic Journal of International Law (2018) pp. 154-188.

19 Act 418/2017 on the Provision and Reception of International Assistance, 28 June 2017, Article 1.

$20 \quad$ Ibid., Article 1, items 2) and 1) respectively. The markedly differing Swedish and Finnish approaches to the EU Common Security and Defence Policy, further, is analysed by S. Heinikoski in 'Framing of the new CSDP in militarily non-aligned Finland and Sweden: Promotion of national interests or a step towards a European Security Community?', L'Europe en formation, number 389 (2019) pp. 161-176. 
Judging from the text of Article 42(7) it constitutes a binding commitment for the EU member states to aid and assist one another by all the means in their power in accordance with Article $5^{1}$ of the UN Charter. The question is why it is not considered a binding obligation by Sweden as opposed for instance to the obligation contained in Article 5 of the NATo Treaty. An argument that sometimes occurs is that the lack of organizational infrastructure and the presumed lack of political commitment beefing up the collective defence clause in Article 42(7) prevent the clause from becoming legally binding.

Ove Bring formulates the matter well (although he considers the mutual defence clause to be legally binding, at least for Sweden's part):21

The difference between Article 42(7) of the TEU and the NATO treaty's Article 5 does not lie so much in the wording as in the more developed institutional mechanisms which give substance to the obligation of the NATO states and which lack any equivalence in the EU context. It is clear that the credibility of the mutual defence clause [the exact translation from Swedish would be "security policy solidarity clause"] of the EU would increase if the member states, jointly and in groupings, would be able to show an existing defence policy cooperation of high value. ${ }^{22}$

In contrast, NATO contains both the infrastructure and political commitment to actually be considered a binding collective defence pact. Recently, the commitment to the collective defence pact in Article 5 has begun to be doubted among countries in Europe. ${ }^{23}$ It remains to be seen whether the perceived weakening US commitment will entail that Article 5 in time will be considered less legally binding too.

If we play with the thought that Article $42(7)$ of the TEU actually is binding, then there would suddenly be an international obligation approved by Parliament as required as one among several possible legal bases for sending Swedish armed forces abroad stated in Article 15:16 of the Instrument of Government. This international obligation is an obligation of aid and assistance of every member state by all the means in their power in case a member state is the victim of armed aggression on its territory.

Article 15:16 in the Swedish Instrument of Government cannot reasonably be more demanding than this. The Swedish Constitution cannot reasonably

\footnotetext{
21 Supra note 2.

$22 \quad$ O. Bring, supra note 2, p. 83.

$23 \quad C f$. the interview with President Emmanuel Macron in 'A president on a mission', The Economist, November 9th 2019, pp. 17-20.
} 
demand that in order for an international obligation to be accepted as an authorization of the government to send Swedish armed forces to other countries, the international obligation must be unconditional and automatic.

The statements on bindingness in the Government Official Reports of 2016 and 2018 that we have seen above - that no international obligation exists for Sweden requiring that a Swedish armed force is deployed or sent abroad - could be interpreted to mean either that the international obligation in question must be so formulated that the states involved in the collective defence agreement are unconditionally required automatically to send armed forces to each other's help or that the international obligation explicitly states what countries should help each other, or both. ${ }^{24}$

The Government Official Report of 2016 states that there is no international obligation requiring Sweden to deploy or send Swedish armed forces abroad whereas the Report of 2018 states that there exists no international obligation requiring that Sweden sends armed forces to Finland in support of Finland. ${ }^{25}$

It is highly unlikely that the text of a collective defence treaty would either be so imperative so as to prescribe the automatic assistance by the other parties in particular by military means in case of an armed attack or that the treaty would be so explicit with respect to the names of the states that would be involved in the collective defence scheme that it would enumerate the obligations of every particular country involved, at least if the treaty is multilateral and involves many parties. If it is a bilateral treaty, it would be more obvious what countries would be involved and what the obligations of the two parties would be toward each other (which would not prevent other countries from offering their help too in case of an armed attack on either of the parties to the bilateral agreement, or any of the parties to a multilateral agreement for that matter).

If we continue playing with the thought that Article 42(7) is binding despite the statements in the Swedish official documents dealing with the deepened defence co-operation between Sweden and Finland, then there would be constitutional legal support for the government (independently) to make decisions on the sending of Swedish armed forces abroad in order to assist another EU member state in case of an armed attack on the member state's territory. The member state could be Finland, for instance.

$\begin{array}{ll}24 & \text { See supra note } 9 . \\ 25 & \text { Ibid. }\end{array}$ 


\subsection{The Case of France under Article 42(7)}

In the case of France in 2015 when France requested assistance from the other members of the EU after having been hit by a non-state terrorist attack by Is, Sweden was one of the states which assisted France as mentioned earlier. ${ }^{26}$ Sweden did not pronounce on the legal quality of Article 42(7) at all at the time of the terror attacks in Paris or at the time when it provided its assistance to France, but then neither did Sweden denounce that Article 42(7) would be legally binding. The Swedish government did, however, bring parts of its projected military assistance to France before Parliament for approval which the government arguably would not have had to do had it considered Article $42(7)$ of the TEU as an international obligation already approved by Parliament under Article 15:16 of the Instrument of Government. ${ }^{27}$

This would suggest, on the one hand, that the Swedish government does not consider Article 42(7) to constitute an international obligation of the kind intended under Article 15:16; at issue was merely the sales of ammunition to France, but if the sending of armed forces would have been allowed due to an international obligation under Article 15:16 then presumably the selling of ammunition would also have been allowed. On the other hand, the decision proposed by the government to Parliament, which the Parliament adopted, referred to the request for ammunition "presented by France 'while relying on Article $42(7)$ of the Treaty on European Union'" 28 This at least suggests that Sweden considers Article 42(7) relevant and applicable in the situation involving France having been the subject of an armed attack.

26 The Swedish assistance to France included the sales of ammunition, the provision of transport aircraft, and staff officers to the United Nations Multidimensional Integrated Stabilization Mission in Mali (MINUsma) (Aktuell debatt om Sveriges deltagande i kampen mot Daish (Current debate on Sweden's participation in the fight against Daesh) 26 January 2016, Riksdagens protokoll (Parliamentary record) 2015/16:58, address 2, Ms Margot Wallström Foreign Minister, < data.riksdagen.se/fil/219Bo839-BCA5-433F-8E556B7594EDA63F $>$, visited on 20 August 2020.

27 Regeringens proposition (government bill) 2015/16:153 Stöd till Frankrike med försvarsmateriel (Support to France with defence materiel), 17 March 2016; decision by parliament, 25 May 2016, <https://www.riksdagen.se/sv/dokument-lagar/arende/ betankande/stod-till-frankrike-med-forsvarsmateriel_H3oiFöU15>, visited on 20 August 2020 .

28 Proposition 2015/16:153, supra note 27, p. 3; decision by parliament 25 May 2016, supra note 27. In the bill the government also argued that the Swedish assistance to France gives credibility to Article $42(7)$ in the TEU (under which Sweden presumably has no collective defence obligations) and the European security policy in its entirety, see supra note 27, p. 5 . 
In the context of the consideration of what assistance Sweden would render France following the French request, the Swedish Foreign Minister Ms. Margot Wallström did make some seemingly clear-cut although perhaps in reality nebulous statements with direct bearing on the issue of the obliging quality of Article 42(7) of the TEU. Thus clarifying, or further obscuring, the actual Swedish position on the binding or non-binding quality of Article 42(7), the Swedish Foreign Minister stated the following at an information and consultation session with the Committee on European Union Affairs in December $2015: 29$ "[Article] 42.7 contains a legal obligation to assist another member state who is the victim of an armed aggression on its territory. There is no exception from mutual solidarity in the EU Treaty, so we have obliged ourselves [in Swedish: vi har förpliktat oss] to render assistance."30 And, "I want to make clear that it is the defence clause [in Swedish: försvarsklausulen] which is invoked, and it is binding." 31

Judging from the ordinary meaning of the words, these statements would seem clear and unambiguous enough, and being pronounced by the Minister for Foreign Affairs in an official setting, they might be taken for the official position of the Swedish government, but then again judging from other Swedish official pronouncements this might not be so. These perhaps illusorily clear-cut statements by the Swedish Foreign Minister are noted, but will not be further analysed for the time being. We will come back to the issue of the apparently ambiguous Swedish official view of the legally binding quality of Article $42(7)$ of the TEU later on.

The fact that both the government and in the end also Parliament were careful to point out that the Swedish assistance to France was provided subsequent to a request based on Article 42(7) of the TEU is noteworthy also because the very issue of Article 42(7) became controversial in the debate in Parliament. One of the political parties, the Swedish Democrats, was of the opinion that the passage "while relying on Article 42(7) of the Treaty on European Union"

Riksdagen, Uppteckningar vid EU-nämndens sammanträden 2015/16:20, 11 December 2015, § 4 Utrikes frågor, Utrikesminister Margot Wallström, Återrapport från möte i Europeiska unionens råd för utrikes frågor den 16 november 2015, Information och samråd inför möte i Europeiska unionens råd för utrikes frågor den 14 december 2015, anförande 141 respektive 150, Utrikesminister Margot Wallström (Parliament, Notes taken at the meetings of the Committee on European Union Affairs 2015/16:20, 11 December 2015, § 4 Foreign affairs, Foreign Minister Margot Wallström, Report from the meeting with the Foreign Affairs Council of the European Union on 16 November 2015, Information and consultation before the meeting of the Foreign Affairs Council of the European Union on 14 December 2015, address 141 and 15 o respectively, Foreign Minister Margot Wallström). 
should be deleted from the decision of Parliament. ${ }^{32}$ The motivation for the deletion of the reference to Article 42(7) was that although the terrorist acts against France represented a terrible tragedy and it was in the Swedish national interest to assist the French efforts to fight Muslim fundamentalism, this Swedish national interest existed completely independently of Sweden being a member of the EU or not in the view of the Swedish Democrats. ${ }^{33}$ Thus, the Swedish Democrats continued, it is immaterial whether France requests help in accordance with the TEU or not - Sweden's interest in contributing would be there in this case anyway. ${ }^{34}$ In the debate in Parliament, a representative of the Swedish Democrats develops a little further why he thinks Parliament in its decision should neglect the fact that France invoked Article 42(7) in the TEU: "The EU is no supranational framework for the defence of Europe", he says, "defence issues within the EU should be international." 35

If Finland, hypothetically, would be the subject of an armed attack, Finland could likewise invoke Article 42(7) in the TEU and Sweden among other members of the EU could aid and assist Finland by all the means in their power. Whether we consider Article 42(7) binding or not, Article 42(7) would at least offer a possible international legal framework for a military operation in the collective self-defence of Finland. If Article 42(7) hypothetically was considered binding, the Swedish government might decide to send Swedish armed forces to Finland in accordance with Article 15:16 in the Swedish Instrument of Government.

Hypothetically again, even if Article 42(7) was considered binding and was considered an "international obligation approved by the Riksdag" the Swedish government could voluntarily submit the matter to Parliament for the latter's approval in order to create the broadest political basis possible for the action in Sweden. Submitting the matter to Parliament on the other hand would slow down the decision-making procedure, which would typically be negative in a situation where Finland would need assistance in defending itself against an armed attack; the Government Official Report of 2018 draws the conclusion that if Parliament is supposed to be involved in the decision-making on the sending of Swedish armed forces to Finland in case of an armed attack on

\footnotetext{
32 Motion (motion) 2015/16:3374 by Mr Michael Jansson och Mr Roger Richtoff.

33 Ibid.

34 Ibid.

35 Debate in parliament, 19 May 2016, Support to France with defence equipment, address 171 Mr Mikael Jansson, <https://www.riksdagen.se/sv/dokument-lagar/arende/betankande/ stod-till-frankrike-med-forsvarsmateriel_H301FöU15>, visited on 20 August 2020.
} 
Finland, the current time for decision-making would have to be substantially reduced. ${ }^{36}$

If Article 42(7) is not considered binding by Sweden, the Swedish government would have to ask for Parliament's approval under Article 15:16 in the Swedish Instrument of Government before Swedish armed forces could be sent to Finland.

If Sweden was the subject of an armed attack, it is thinkable that Sweden would invoke Article 42(7) under the TEU and even that Sweden would hope that some countries considered binding the collective defence clause under Article 42(7). As we saw above, Finland has already filled any potential hole in the chain of legal argument by adopting a law providing a legal basis for giving military assistance to other countries. ${ }^{37}$

\subsection{The Political Decision by the Swedish Government to Aid}

Presuming that Article 42(7) was considered binding by Sweden and that the collective defence clause in Article 42(7) was considered "an international obligation approved by the Riksdag", there would still have to be some decision-making by the Swedish government. ${ }^{38}$ It is unlikely that the legislation would ever provide that not even the government would be involved in the decision-making on what aid and assistance should be provided, if any, in a situation of collective self-defence. It is similarly unlikely that it would be delegated to the armed forces automatically to take military action in collective self-defence in aid of another EU member, even if Article 42(7) hypothetically would be considered an "international obligation" by the Swedish government. Thus, there would have to be some form of political decision-making on the part of Sweden even if Article 42(7) was considered binding in principle.

In the terms of reference of the commission of inquiry of 2016 on the conditions under the Instrument of Government for deepened defence cooperation (with Finland most immediately) an important qualification is made in the form of a passage requiring that any Swedish participation in collective

$36 \quad$ SOU 2018: 31 , supra note 8 , pp. 73,78 .

37 See supra note 18 et seq.

38 As Hugemark and Tunberger, supra note 1, p. 22 write, no declaration of solidarity or security guarantee means an automatic military intervention. This also applies to Article 5 in the NATO treaty, according to the same authors (ibid.). In regeringens proposition (government bill) 2008/o9:140 Ett användbart försvar (A useful defence) 19 March 2009, p. 20, the Swedish government states (translated into English by the current author): "An Article 5 decision thus entails no automatic obligation for any member of the alliance to take any pre-specified measures" (emphasis added). Cf. also Bring, supra note 2, p. 83; Dyson and Konstantinides, supra note 1, p. 69. 
self-defence must be preceded by "the necessary political decisions." ${ }^{39}$ The terms of reference read:

An [commission of inquiry] shall analyze the conditions for Sweden, provided that the necessary political decisions are made, to act jointly with another state with military resources in order to meet an armed attack against any of the states and to prevent violations of the territory during peace and war between foreign states. ${ }^{40}$

Presumably, in line with what has been argued above, Swedish participation in collective self-defence operations will always be preceded by the necessary political decision-making; either the government would make the necessary political decisions alone or the government together with the Parliament would make the necessary political decisions.

In the case of a legally binding collective defence agreement, it is likely that the Swedish government alone would make the decisions whereas in the case of a non-legally binding collective defence agreement, the government would need Parliament's approval. What the qualification in the directive means, probably, is that under no circumstances should Sweden enter into a legally binding collective defence agreement; the "necessary political decisions" clause seems to be regarded as an absolute bar guaranteeing that this will not happen.

This conclusion is confirmed in the recent government bill to Parliament of 2020 on operational military support between Sweden and Finland cited earlier. ${ }^{41}$ In order to dispel any misunderstandings, it is stated early in the government bill that " $[\mathrm{i}] \mathrm{t}$ must be emphasized that Sweden and Finland have not agreed to mutual defence obligations; the Swedish-Finnish defence cooperation includes creating actual conditions for joint operational action with military resources, not obligations to act in a certain way in a particular situation."42

39 Direktiv (Dir.) 2015:111, p. 1.

40 Ibid., emphasis added. In the context of the Swedish ratification of the indubitably binding Host Nation Support Treaty with NATO (entered into in 2014), the Swedish government also emphasized the element of voluntariness with respect to any action taken within the framework of the treaty: “ ... Sweden decides if and when NATo-led activites may take place on Swedish territory and in such a case also the content of the activities" (regeringens proposition (government bill) 2015/16:152 Samförståndsavtal om värdlandsstöd (Host Nation Support Treaty) 17 March 2016, p. 31).

$41 \quad$ Cf. supra note 10.

42 Supra note 10, p. 11; in Swedish: "Det ska understrykas att Sverige och Finland inte har åtagit sig ömsesidiga försvarsförpliktelser; det svensk-finska försvarssamarbetet innefattar 


\subsection{Obligation or No Obligation?}

This seemingly unambiguous Swedish position is obscured a little, however, by the wording of a passage in the latest report on the defence by the parliamentary Defence Commission entitled "Force to defend: The direction of the security policy and the design of the military defence 2021-2025."43 Under the heading of "NATO" the report states the following on the subject of collective self-defence (or "collective security guarantees" which is the terminology used in the Defence Commission Report with respect to NATO)

The right of a state to individual or collective self-defence in the event of an armed attack constitutes a fundamental international legal principle which is regulated in Article $5^{1}$ of the UN Charter. This principle is the starting point for the defence obligations which are found in the NATO Treaty Article 5 and in Article 42.7 in the EU Lisbon Treaty. ${ }^{44}$

Of course, Sweden can still reasonably maintain the position that the "defence obligations" in Article 42(7) of the TEU are only binding on other members of the EU and not on Sweden due to the provision on "the specific character of the security and defence policy of certain Member States" referring to the neutral and non-aligned EU members, in the second sentence of Article 42(7) first paragraph. ${ }^{45}$

att skapa faktiska förutsättningar för ett gemensamt operativt agerande med militära resurser, inte skyldigheter att agera på ett visst sätt i en viss situation." See also Regeringens proposition (government bill) 2020/21:30 Totalförsvaret 2021-2025 (The Total defence 2021-2025) 14 October 2020, p. 28.

43 Värnkraft: Inriktningen av säkerhetspolitiken och utformningen av det militära försvaret 2021-2025, Försvarsberedningens rapport (Report of the Defence Commission), Departementsserien (Ds) (Ministry Publications Series) 2019:8. The Defence Commission is a consultative body consisting among others of representatives of all political parties represented in Parliament.

Ds 2019:8, ibid., p. 88, emphasis added; cf. also Säkerhet i ny tid (Security in a new era), sou 2016:57, p.49.

$45 C f$. the government bill presented to Parliament at the time of the ratification of the Lisbon agreement (regeringens proposition (government bill) 2007/08:168, supra note 10) p. 252. Since the early 199os Sweden pursues a policy of 'non-alignment' and no longer a policy of neutrality with a view to staying neutral in case of war between foreign states (see for instance, K. Engelbrekt, 'Småstaten Sverige: numera bindningsbenägen?', ('Small state Sweden: now bindable?'), in G.Herolf and B. Huldt (eds.), På egen hand eller tillsammans? Sverige i det nya Europa (On your own or together with others? Sweden in the new Europe) (Kungl Krigsvetenskapsakademin, Stockholm, 2013) pp. 228-254, p. 228; G. Herolf and B. Huldt, 'Sverige i det framtida Europa', in G. Herolf and B. Huldt (eds.), ibid., pp. 279-292, p. 279; Minister for Foreign Affairs Ms Ann Linde, Statement of Government Policy in the Parliamentary Debate on Foreign Affairs Wednesday 24 February 2021, https://www. 
The exact same two sentences just quoted on the right of a state to individual or collective self-defence in the event of an armed attack and the expression of this principle in the NATO and Lisbon treaties reappear under the heading of "Swedish security policy" except for one term which is exchanged: "This principle is the starting point for the solidarity which is found in the NATO Treaty Article 5 and in Article 42.7 in the EU Lisbon Treaty." 46 "Defence obligations" is exchanged for "solidarity", without any further explanation. Then again, under the heading of "Cyber defence", the Defence Commission states that "[b]oth the EU and NATO have laid down that a cyber attack can trigger obligations under Article 42.7 of the EU Treaty and under Article 5 of the Washington treaty respectively." ${ }^{\prime 7}$

Perhaps contributing further to the (intended or unintended) blurring of the Swedish position, it is stated in the report of the Defence Commission that "it is in the Swedish interest to strengthen the EU's capacity to act as a security policy actor."48 It is added that " $\mathrm{t}]$ his also has significance for the credibility of Article 42(7) in the EU Treaty."49

government.se/speeches/2021/o2/statement-of-foreign-policy/, visited on 5 March 2021. Upon Sweden's entry into the EU in 1995, it was much debated including in the academic doctrine whether Sweden would be able to continue to pursue its time-honoured policy of neutrality or not (for two different positions, see for instance G. Lysén, 'Some views on neutrality and membership of the European Communities: The case of Sweden' 29:2 Common Market Law Review (1992) pp. 229-255; P. Cramér, Neutralitet och europeisk integration (Neutrality and European integration), (Norstedts Juridik, Stockholm, 1998) pp. 598, 645-646); in P. Cramér, ibid., further, a thorough historical background is provided in a comparative perspective on the significance and relevance of neutrality to the Swedish membership in the EU; the development of the modern Swedish policy of non-alignment since the beginning of the 199os is carefully explained by Ahlin, supra note 5, "The policy of neutrality was buried in the 199os", P. Ahlin writes, ibid., p. 44; O. Bring, writing with a focus on Sweden, is of the opinion that "neutrality as an intellectual platform for action, as a unilateral or multilateral policy, is stone-dead." (Neutralitetens uppgång och fall - eller den gemensamma säkerhetens historia (The rise and fall of neutrality - or the history of common security) (Atlantis, Stockholm, 2008) p. 398; Mr Håkan Malmqvist, Swedish ambassador to NATO in 2014-2018, in 2018 wrote that "[w] hile still militarily non-aligned, Sweden is no longer aiming for neutrality in case of a conflict, as was the case during the Cold War. Back then our doctrine stated that we were non-aligned in peacetime with the purpose of maintaining neutrality in war." ('Sweden and NATO - 23 years down the road, 11 January 2018, https://www.nato.int/docu/review/articles/2018/o1/11/sweden-and-nato-23years-down-the-road/index.html, visited on 24 August 2020).

46 Ds 2019:8, supra note 43, p. 102, emphasis added.

$47 \quad$ Ibid., p. 252.

$48 \quad$ Ibid., p. 291.

49 Ibid.; cf. also regeringens proposition (government bill) 2020/21:30, supra note 42, p. 77, emphasis added. 
Thus, although the lack of obligations under Article 42(7) for Sweden's part are generally heavily emphasized, it is simultaneously emphasized that it is in the Swedish interest to strengthen the EU as an actor in the field of security policy and that the credibility of Article 42(7) is important, not Article 42 in general but specifically Article 42(7). The question could be raised why the credibility of a non-binding mutual defence clause - at least non-binding for Sweden - is considered important by Swedish official representatives, and, conversely, if Swedish official representatives consider the credibility of Article 42(7) important, why Sweden would continue claiming that it is not bound by the mutual defence clause in Article 42(7). From the legal point of view at least, and perhaps also from a political point of view, the legally binding form of an international commitment normally serves to strengthen the credibility of the commitment in question.

Perhaps the Defence Commission means that by strengthening the EU's capacity to act, the institutional and logistical underpinnings of the mutual defence clause would be strengthened and thereby the mutual defence machinery of the EU would become more credible, just like the mutual defence commitment under the NATO Treaty. Then, if the EU would become organizationally stronger and thereby more credible as a platform for the exercise of collective self-defence, Sweden could perhaps start considering itself bound by the mutual defence clause in Article 42(7). Perhaps the Defence Commission means that currently Article 42(7) is just not credible, due to the lack of capacity of the EU to act in the security policy field. For the time being what the Defence Commission means exactly is shrouded in mystery.

Also, it is added in the report of the Defence Commission, still under the heading of "Swedish security policy", that "neither the unilateral Swedish 'declaration of solidarity', nor the Nordic declaration of solidarity, nor the bilateral nor the regional defence collaborations which Sweden is part of encompass any mutual defence obligations and are therefore no compensation for the collective commitments which exist for the members of NATO."50 The same sentence reappears, now under the heading of "Opportunities and limitations regarding common planning and coordination", with the exception of the mention of the Nordic declaration of solidarity (which does not include defence cooperation or the use of military means). ${ }^{51}$

Ds 2019:8, supra note 43, p. 104; still, arguably, in a more general sense all the defence collaborations that are mentioned do indeed constitute compensation in different forms for the lacking Swedish membership in NATO. 
There are no material obstacles in the Swedish Instrument of Government to deepened international defence cooperation at all. The conclusion in the Government Official Report of 2016 - on the conditions under the Swedish Instrument of Government for deepened defence cooperation - that nothing in the Swedish Instrument of Government hinders deepened international defence cooperation is equally valid with respect to non-binding agreements on collective self-defence as with respect to legally binding collective defence pacts. ${ }^{2}$ Thus, there are no constitutional legal hinders excluding a binding collective defence commitment on Sweden's part (in fact, as we have seen, one can play with the thought that Sweden has already entered into one through Article 42(7) in the TEU), and even if Sweden would enter into a legally binding collective defence treaty, the necessary political decisions would still arguably always have to be made before Sweden actually would start contributing militarily to the defence of another country.

The only remaining explanation of the qualification in the directive to the official inquiry of 2016 - the 'necessary political decisions' condition - is that it is a political signal, primarily for Swedish domestic consumption, that Sweden will not enter into a binding collective defence treaty at all.

If Sweden is regarded as having already entered into a binding collective defence treaty with the other members of the EU, then it becomes obvious that political decisions will precede the execution of the assistance; Sweden did make political decisions before assisting France in different ways in the wake of the terror attacks in Paris in 2015. The Swedish government decided that it wanted to help France and decided what this help would consist of; in the case of the sale of ammunition, Parliament decided that it would approve the decision to sell ammunition proposed by the government. ${ }^{53}$

\section{Swedish Constitutional Ground for Collective Defence Operations}

\subsection{Defence of the Realm}

From the point of view of the Swedish Constitution, the question arises on the basis of which of two possible articles in the Instrument of Government - Article 15:13 and Article 15:16 - that collective self-defence measures may and should be taken.

Cf. sou 2016:64, supra note 8, p. 115; cf. also A. Eka, J. Hirschfeldt, H. Jermsten and K. Svahn Starrsjö, Regeringsformen - med kommentarer, second edition (Karnov Group, Stockholm, 2018) p. 715 . 
Article 15:13 stipulates that " $[\mathrm{t}]$ he Government may deploy the armed forces of the Realm in accordance with international law to meet an armed attack against the Realm or to prevent a violation of its territory."

Article $15: 16$ on the other hand stipulates, firstly, that "[t]he Government may send Swedish armed forces to other countries or otherwise deploy such forces in order to fulfil an international obligation approved by the Riksdag." Secondly, Article 15:16 stipulates that "Swedish armed forces may also be sent to other countries or be deployed if: 1 . It is permitted by an act of law setting out the conditions for such action; or 2 . The Riksdag permits such action in a special case."

Individual self-defence operations, obviously, are based on Article 15:13 of the Instrument of Government. Article 15:13 talks about an armed attack against the Realm and states that the government may deploy the armed forces of the Realm to meet the attack. Collective self-defence is not talked of as such in the existing commentaries to the Swedish Constitution. This is probably because collective self-defence has not been regarded as something that would reasonably ever concern the Swedish armed forces. However, recently this situation has changed. ${ }^{54}$

In one of the existing semi-official commentaries on the Swedish Constitution, the issue of collective self-defence is now touched upon but the issue is not put in those exact terms. ${ }^{55}$ Under Article 15:13 the commentary mentions the Swedish so called 'declaration of solidarity' which is a unilateral declaration originally pronounced in a report issued by the parliamentary Defence Commission in 2007 stating that "Sweden will not remain passive if a disaster or an attack would hit another [EU] member state or Nordic state. We expect these countries to behave in the same way if Sweden is hit."56

This is illustrated among other things by the great number of official inquiries of different kinds dealing with issues directly or, mostly, indirectly relating to collective self-defence: Försvarspolitiskt samarbete - effektivitet, solidaritet, suveränitet (Cooperation in defence policy - effectiveness, solidarity, sovereignty), supra note 2; Deltagande med väpnad styrka i utbildning utomlands: En utökad beslutsbefogenhet för regeringen (Participation with an armed force in training abroad: A broadened decision-making capacity of the Swedish government), SOU 2015:1; Samförståndsavtal med Nato om värdlandsstöd (Host Nation Support Agreement with NATO), Ds 2015:39; SOU 2016:57, supra note 44; SOU 2016:64, supra note 8; sou 2018:31, supra note 8.

55 Eka, Hirschfeldt, Jermsten and Svahn Starrsjö, supra note 52, p. 715.

56 Säkerhet $i$ samverkan, Försvarsberedningens omvärldsanalys (Security in cooperation, Analysis of the surrounding world by the Defence Commission) Ds 2007:46, p. 11; see also regeringens proposition (government bill) 2008/og:140, supra note 38, pp. 9, 29-30; Försvarsutskottets betänkande (Defence Committee report) 2008/og:FöUı Försvarets 
The Swedish 'declaration of solidarity' is a unilateral all-inclusive collective self-defence undertaking vis-à-vis the other EU members and the Nordic countries combined with an expectation that the other EU members and the Nordic countries will act in a similar way if Sweden is hit. It can be noted that in relation to the other EU members, the 'declaration of solidarity' includes both Article 222 in the Treaty on the Functioning of the European Union (TFEU) entitled 'Solidarity clause' and which talks of "natural or man-made disasters", among other things, and Article 42(7) in the TEU which talks of "armed aggression." 57 The form in which this particular (unilateral) collective defence arrangement is expressed is non-legally binding. ${ }^{58}$ The potential Swedish constitutional implications of the 'declaration of solidarity', if there are any, are

inriktning (The direction of the defence), adopted by parliament by consensus 16 June 2009, pp. 1, 12, 16-17 https://www.riksdagen.se/sv/dokument-lagar/arende/betankande/ forsvarets-inriktning_GWoıFöU1o, visited on 21 August 2020; Ds 2019:8, supra note 43, p. 102; Bring, supra note 2, pp. 81-89.

Incidentally, the merger of the two articles now belonging to two different treaties in the TEU would be quite natural, according to Van Vooren and Wessel, supra note 1, p. 404; Dyson and Konstantinides, supra note 1, pp. 69-70 share this opinion as does Koutrakos (2011), supra note 1, p. 241. In Fö 2013:B, supra note 2, p. 64, it is pointed out that no other country has made a solidarity commitment similar to the Swedish one; it is unique among the EU members and the Nordic non-EU members. On possible implications of the 'declaration of solidarity', see B. Hugemark (ed.), Till bröders hjälp: Med sikte på en svensk solidarisk strategi (To help brothers: With a view to a Swedish solidarity strategy) (Kungl Krigsvetenskapsakademin, Stockholm, 2011).

$5^{8} \quad$ The potential legal significance of unilateral declarations will not be investigated further here. With respect to the Swedish 'declaration of solidarity' suffice it to say that since the first condition in order for a legally binding commitment to arise is that Sweden intends to create a binding commitment, which Sweden must be presumed not to have intended either at the time of the original pronouncement of the declaration or at any later time, it would seem as if any possibility of the unilateral 'declaration of solidarity' giving rise to an international legal obligation on Sweden's part is excluded. In addition, unilateral declarations are not binding on other states unless the other states accept the declaration. Thus, no legally binding obligations could arise on the part of other states as a result merely of the Swedish unilateral 'declaration of solidarity' which nevertheless refers to the Swedish expectation that the other countries will behave in the same way if Sweden is hit. See further, among many other works, United Nations International Law Commission, 2006, Guiding Principles applicable to unilateral declarations of States capable of creating legal obligations, with commentaries thereto, Text adopted by the International Law Commission at its Fifty-eighth session, in 2006, and submitted to the General Assembly as a part of the Commission's report covering the work of that session (A/61/10); Yearbook of the International Law Commission, vol. II Part 2, Report of the Commission to the General Assembly on the work of its fifty-eighth session, pp. 159-166; O. Dörr, 'Declaration', in Max Planck Encyclopedias of International Law, published under the auspices of the Max Planck Foundation for International Peace and the Rule of Law under the direction 
not dealt with in the previously mentioned commentary to Article 15:13, or anywhere else in this or any other commentary to the Instrument of Government.

A little more concrete perhaps than the unilateral 'declaration of solidarity' is the defence cooperation decided upon between Sweden and Finland. ${ }^{59}$ This defence cooperation stretches from situations of peace to situations of war and includes all levels of the participants' defence..$^{60}$ At the war end of the scale, the Swedish-Finnish defence cooperation closely resembles a collective defence

of Rüdiger Wolfrum, last updated August 2019 <https://opil.ouplaw.com/view/10.1093/ law:epil/978o19923169o/law-978o19923169o-e1397?rskey=RipmR1\&result=1\&prd=MPIL >, visited on 21 August 2020; V. Rodríguez Cedeño and M. I. Torres Cazorla, 'Unilateral Acts of States in International Law', in Max Planck Encyclopedias of International Law, ibid., last updated January 2019.

Memorandum of Understanding Between The Government of The Republic of Finland and The Government of The Kingdom of Sweden on Defence Cooperation, 9 July 2018; cf. also Statement of Intent on Enhanced Operational Cooperation among The Ministry of Defence of the Republic of Finland and The Ministry of Defence of the Kingdom of Norway and The Ministry of Defence of the Kingdom of Sweden, 23 September 2020, $<$ www.regeringen.se/4a7675/globalassets/regeringen/dokument/forsvarsdepartementet/ soi/trilateral-statement-of-intent-on-enhanced-operational-cooperation-2oog23.pdf>, visited on 4 November 2020; "Finland, Norway and Sweden enhance their trilateral military operations cooperation", Opinion piece from Ministry of Defence, 23 September 2020, <www.government.se/opinion-pieces/2020/og/finland-norway-and-swedenenhance-their-trilateral-military-operations-cooperation/>, visited on 4 November 2020; cf. further Trilateral Statement of Intent among The Department of Defense of the United States of America and The Ministry of Defence of the Republic of Finland and The Ministry of Defence of the Kingdom of Sweden of 8 May 2018, www.government. se/49993c/globalassets/government/dokument/forsvarsdepartementet/2018/trilateralstatement-of-intent-8th-may-2018.pdf $>$, visited on 4 November 2020.

6o Memorandum of Understanding Between The Government of The Republic of Finland and The Government of The Kingdom of Sweden on Defence Cooperation, supra note 59, section 2, items 3 and 4; however, under item 3, second sentence, "[t]his MoU does not contain mutual defence obligations." Cf. also Statement of Intent on Enhanced Operational Cooperation among The Ministry of Defence of the Republic of Finland and The Ministry of Defence of the Kingdom of Norway and The Ministry of Defence of the Kingdom of Sweden, ibid., under the heading of "Scope": "This trilateral Statement of Intent outlines the common ambition of the Participants to be able and ready to conduct operations in crisis and conflict if so decided, noting that Norway plans to transfer command to NATO in crisis and war." And further, "[i]n order to improve our interoperability and readiness to give military support between us we will undertake the necessary preparations, aiming at enhancing our defence capability and serve as a deterrent from aggression." And, "[a] possible outcome is operations planning for areas of common concern, for example the northern parts of Finland, Norway and Sweden (North Calotte and expand to other areas as required) and improved interoperability between our armed forces that enable common military action if decided." However, "[t]his Trilateral Statement of Intent does not entail any mutual defence obligations." Also, "Denmark and Iceland are to be informed on a regular basis as the cooperation proceeds." 
pact; however, nowhere is this term used. In the same semi-official commentary to the Swedish Constitution as was referred to above on the subject of the unilateral 'declaration of solidarity', the Finnish-Swedish defence cooperation is also commented upon, briefly, under Article 15:13 in the Instrument of Government; there are no Swedish constitutional hinders, as far as the commentary can see, to the defence cooperation. ${ }^{61}$

Since the defence cooperation with Finland, although briefly, is taken up under Article 15:13 and only under this article in the only commentary to the Swedish Instrument of Government that mentions collective defence at all (although not using that term) in addition to individual defence, it must be concluded that it is under Article 15:13 that collective self-defence measures legally belong according to qualified Swedish constitutional lawyers, at least when the collective self-defence measures are undertaken in the form of standing arrangements for cooperation with a view to possible instances of active measures of collective self-defence being taken in the future.

On the subject of collective self-defence, furthermore, it can be noted that Article 42(7) of the TEU is not mentioned in the semi-official commentary on the Swedish Constitution otherwise touching briefly upon the issue of collective self-defence both in the form of the defence cooperation between Sweden and Finland and in the form of the Swedish unilateral collective defence undertaking vis-à-vis the same countries as are members of the EU plus Norway and Iceland. ${ }^{62}$ Nor is the TEU Article 42(7) mentioned in any of the other existing commentaries on the Instrument of Government. ${ }^{63}$

\subsection{Deepened Defence Cooperation under the Swedish Constitution}

In the previously mentioned Government Official Report of 2016, the matter of the Swedish constitutional basis for collective self-defence cooperation was carefully investigated. ${ }^{64}$ The inquiry was carried out against the backdrop of "the Swedish 'declaration of solidarity' and Sweden's cooperation in the area of defence with Finland, among others." ${ }^{25}$ As in the semi-official commentary to the Swedish Instrument of Government quoted above, the terminology used

\footnotetext{
61 Eka, Hirschfeldt, Jermsten and Svahn Starrsjö, supra note 52, p. 715.

62 Eka, Hirschfeldt, Jermsten and Svahn Starrsjö, supra note 52.

63 E. Holmberg, N. Stjernquist, M. Isberg, M. Eliason, G. Regner, Grundlagarna: Regeringsformen, Successionsordningen, Riksdagsordningen, third edition (Norstedts Juridik, Stockholm, 2012); T. Bull, F. Sterzel, Regeringsformen: En kommentar, fourth edition (Studentlitteratur, Lund, 2019); J. Nergelius, Svensk statsrätt, fourth edition (Studentlitteratur, Lund, 2018).

64 sou 2016:64, supra note 8.

65 Ibid., p. 11.
} 
is not the one explicitly of 'collective self-defence', but rather 'defence cooperation', 'deepened defence cooperation' or 'joint action with another state in order to meet an armed attack against any of the states.' ${ }^{66}$

As a premise for the commission of inquiry, it was laid down in the terms of reference that "from the Swedish perspective there are no other limitations of principle to a deepened defence cooperation than the cooperation not involving mutual defence obligations." ${ }^{\prime 67}$ Combined with the stated task of the commission of inquiry "to analyse the conditions under the Instrument of Government ... for Sweden to act with military resources jointly with another state in order to meet an armed attack against any of the states" ${ }^{\prime \prime} 8$ which reasonably refers to what is more commonly denoted as 'collective self-defence', the limitation should reasonably be read as not limiting the potential content or extent of the joint - or collective - military action as such in defence of any of the states, but as limiting the possible legally binding force of any 'deepened defence cooperation', of whatever scope, for Sweden's part. If there are no felt obligations at all with respect to joint (collective) defence action on Sweden's part as a result of a deepened defence cooperation, for instance with Finland, the interest of other countries in cooperating with Sweden in the field of defence would likely decrease.

Also, as mentioned above Sweden has issued a unilateral 'declaration of solidarity' by which Sweden obliges itself to come to the rescue of the other members of the EU, and Norway and Iceland, in case they are subject to an armed attack. ${ }^{69}$ In addition, according to the 'declaration of solidarity', Sweden expects these other states to assist Sweden in a corresponding situation..$^{70}$ Thus, the significant limitation is probably the strictly legal one of Sweden not being prepared to commit to being formally obliged to act in collective self-defence every time the situation would (hypothetically) arise, most immediately with respect to Finland. Sweden wants to be free to decide whether to come to another state's assistance or not in the event of an armed attack.

\subsection{The Sending of Swedish Armed Forces to Other Countries}

Looking at the official Swedish commissions of inquiry having investigated closely the matter of the defence cooperation between Sweden and Finland

66 The term "collective self-defence" (kollektivt självförsvar, in Swedish) is used once in the Government Official Report when the right to collective self-defence under international law is referred to (sou 2016:64, p. 112).

67 Dir. 2015:111, p. 2.

68 Ibid., pp. $1,4$.

69 See supra note 56.

70 Ibid. 
from the legal including the constitutional legal point of view, it turns out that contrary to what might be the impression from the commentary to the Swedish Instrument of Government cited above, Article 15:16 on the deployment of armed forces in addition to Article 15:13 on the defence of the Realm is considered to constitute another indispensable constitutional basis for the potential Swedish participation abroad in actual collective defence measures of another country, Finland in the concrete planning currently. ${ }^{71}$

Whereas Article 15:13 in the Instrument of Government stipulates the purpose for which the armed forces of the Realm may be deployed - to meet an armed attack against the Realm or to prevent a violation of its territory - Article 15:16 does not contain any limitation of the purposes for which or the situations in which Swedish armed forces may be sent to other countries or may be otherwise deployed. The conclusion drawn in the Government Official Report of 2016 on the subject of Article 15:16 with respect to collective self-defence is that this Article does not prevent Parliament from consenting to the deployment of Swedish armed forces in aid of another state..$^{72}$

The following Government Official Report of 2018 takes as its starting point that a Swedish military operation abroad in order to assist Finland in the latter's self-defence against an armed attack would have to be based on Article 15:16 in the Instrument of Government on the sending of Swedish armed forces to other countries (or their deployment otherwise) and not on Article 15:13 on the defence of the Realm. ${ }^{73}$

As to the collective self-defence of Sweden in case of an armed attack, it should be uncontroversial under the existing Instrument of Government that Sweden, and more precisely the Swedish government, would be entitled to ask for military assistance from Finland under Article 15:13. ${ }^{74}$ The Government Official Report of 2018 and subsequently the government bill to Parliament proposes legislation making this clear and laying down further provisions concerning the conditions for the action of the Finnish armed forces on Swedish territory. ${ }^{75}$ With respect to the potential Swedish military assistance to Finland in case of an armed attack on the latter not only the Swedish government but also the Swedish Parliament necessarily has to be involved in the decision-making under Article 15:16, according to the terms of reference of the commission

\footnotetext{
71 SOU 2016:64, supra note 8; sOU 2018:31; supra note 8.

72 SOU 2016:64, supra note 8, p. 107.

73 SOU 2018:31, supra note 8, pp. 13, 44-45.

74 SOU 2016:64, supra note 8, p. 109 et seq.; sou 2018:31, supra note 8, pp. 85-86, 76-78.

75 SOU 2018:31, supra note 8, pp. 27, 186-188; regeringens proposition (government bill) 2019/20:110, supra note 10, § 2.
} 
of inquiry. ${ }^{76}$ According to the terms of reference of the commission of inquiry, further, the procedure for decision-making laid down in Article 15:16 should remain intact. ${ }^{77}$

The primary concern of the commission of inquiry of 2018 was the promptness with which decisions can be made in Sweden on the granting or receiving of military assistance. ${ }^{78}$ Judging from the terms of reference and from the reasoning in the Government Official Report as well as the ensuing government bill to Parliament, there will be no change in the relatively lengthy decision-making procedure involving Parliament in case the granting of military assistance to Finland is considered in the event of an armed attack. ${ }^{79} \mathrm{In}$ case the receiving of aid from Finland is considered, in the event of an armed attack on Sweden, the government alone will make the decision according to a reasonable interpretation of Article 15:13 as well as to the suggestion in the Government Official Report and again in the ensuing government bill. ${ }^{80}$

The Government Official Report of 2018 on operational military support between Sweden and Finland and the ensuing government bill also consider the situation where the two states ask for military assistance from one another in hindering violations of their respective territories without the situation amounting to one of armed conflict. In summary, the Report and the ensuing government bill to Parliament consider and probably rightly so that it is considerably easier to speed up the Swedish decision-making procedure in these cases not involving a situation of armed conflict by adopting legislation empowering the government to make the necessary decisions alone. ${ }^{81}$ This concerns in particular the situation where Sweden would send military troops to assist Finland; as we have seen, decision-making by the government alone is ruled out, according to the Swedish view, in case the Swedish military assistance to Finland would concern helping Finland to meet an armed attack. Quick decision-making on Swedish military assistance to Finland will only be possible in a situation not involving armed conflict.

\footnotetext{
$76 \quad C f$. Dir. 2017:30, p. 4.

77 Dir. 2017:30, pp. 2, 5-6; it was not included in the task of the official inquiry to consider amendments to the Instrument of Government.

78 Dir. 2017:30, pp. 1, 5 .

79 Cf. regeringens proposition (government bill) 2019/20:110, supra note 10, pp. 14-15, 26-27, 76; SOU 2018:31, supra note 8, pp. 27, 186-188; Dir. 2017 :30, pp. 2, 5-6.

8o Proposition 2019/20:110, supra note 10, pp. 15-17, 28-30, 77; SOU 2018:31, supra note 8, pp. 27, 85-89, 186-188.

81 See regeringens proposition (government bill) 2019/20:110, supra note 10, pp. 13-18, 18-34; sou 2018:31, supra note 8 , section 5 , pp. 79-89.
} 


\subsection{Possibility but Not a Pledge?}

There would seem to be a stronger presumption that Sweden would help if Sweden would be party to a binding collective defence agreement compared with the situation if Sweden is not a party to a legally binding agreement. Apart from that, it is not certain that the practical circumstances surrounding the actual decision-making in a particular case would differ that much depending on whether Sweden had made a legally binding commitment or not. There will always be political decisions made on whether to help the country requesting assistance and if so how.

Looking at the (so far) indubitably legally binding NATO treaty, Article 5 stipulates that "if ... an armed attack occurs, each of [the Parties] ... will assist the Party or Parties so attacked by taking forthwith ... such action as it deems necessary, including the use of armed force ...." Obviously, political decisions will be made on the domestic level concerning what action to take in every particular case. ${ }^{82}$

In comparison with the mutual defence clause in Article 42(7) of the TEU, even observers who deny the legally binding force of the clause, either completely or with respect to the neutral and non-aligned member states, maintain that it will have a great political significance. Martin Reichard, for instance, argues that even while there might not exist a legal obligation to assist an attacked state, such assistance is politically very likely to be given in the case of the EU "because of the strong sense of solidarity existing between EU member States today." 83 The important deterrent function of collective self-defence is thus little diminished, Martin Reichard writes. ${ }^{84}$ The reasoning arguably is applicable and perhaps even more strongly so to the Swedish-Finnish relationship and the sense of solidarity between Sweden and Finland. If the intention is there to honour one's commitments (regardless of whether they are legal in form or merely political), the same action is likely to be taken regardless of whether the agreement is expressed in legally binding terms or is only political.

Complete trust in a non-legally binding arrangement could be a little precarious, however. In another Swedish Government Official Report, of 2013, preceding the ones relating more or less directly to the projected deepened defence cooperation with Finland, the investigator discusses what he labels "the blessing of obscurity", not with respect to the relationship of Sweden

$82 \quad$ Cf. supra note 38 et seq.

83 Reichard, supra note 2, p. 213.

84 Ibid., p. 213; cf. also Kuijper et al., supra note 1, p. 69 o. 
with Finland, but with respect to the relationship of Sweden to NATO.$^{85}$ Even though not directly relevant to the Swedish-Finnish cooperation, the reasoning may have some general indirect relevance also to this relationship.

What is labelled "the blessing of obscurity" in the official inquiry of 2013 refers to the (historical) confidence reigning in Sweden that Sweden would be protected by NATO, without Sweden having to contribute to increased tension in Sweden's geographical proximity by becoming a member of the alliance. ${ }^{86}$ There existed a confidence thus that Sweden would be assisted even without legally binding mutual defence commitments. In the official inquiry of 2013 it is pointed out that such an informal arrangement is more uncertain than actually being a member of the alliance; when the political circumstances change members can be expected to be more secure than non-members. ${ }^{87}$

The same reasoning could be applied to the Finnish-Swedish informal deepened defence cooperation; a legally binding agreement is more trustworthy than a non-binding agreement. Arguably, there is every reason to believe that the motivation on both the Finnish and the Swedish side to implement their informal mutual defence commitments will remain very strong. The (so far non-binding) arrangement may even be a way of compensating, slightly, for a perceived waning of the historical "blessing of obscurity."

The official commission of inquiry on the conditions for deepened defence cooperation under the Swedish Instrument of Government emphasizes, even strongly, that Sweden is not prepared to accept any mutual collective defence obligations. ${ }^{88}$ The deepened defence cooperation with Finland means a possibility to cooperate, but not a pledge, states the Swedish government including in its recent government bill to Parliament on a law on operational military support between Sweden and Finland. ${ }^{89}$

It is unlikely, however, that the deepened defence cooperation with Finland would mean unreliable random responses to requests for assistance from either Finland or Sweden; it is more likely that there exists in fact an expectation and even a strong expectation on both sides that both countries will fulfil their non-existing pledges.

85 Fö 2013: supra note 2, p. 69 et seq.

86 Ibid., p. 70.

$87 \quad$ Ibid. A certain degree of obscurity continues to characterize the Swedish security policy stance that "Sweden is not a member of any military alliance. At the same time, Sweden is building security together with others." (regeningens proposition (government bill) 2020/21:30, supra note 42, p. 27 see also p. 68).

88 Dir. 2015:111, supra note 39, p. 2; see also regeringens proposition (government bill) 2014/15:109 Försvarspolitisk inriktning - Sveriges försvar 2016-2020 (Orientation of the Swedish defence policy - the defence of Sweden 2016-2020), 23 April 2015, p. 23 et seq.

89 Regeringens proposition (government bill) 2019/20:110, supra note 10, p. 11; regeringens proposition (government bill) 2014/15:109, ibid., p. 24 . 
On the Finnish side the Act on the Provision and Reception of International Assistance would seem to give witness to a genuine ambition to be able to assist when assistance is requested. ${ }^{90}$ On the Swedish side the unilateral 'declaration of solidarity' encompassing all members of the EU (plus Norway and Iceland) mentioned earlier is a sign that Sweden likewise has the ambition to actually assist when assistance is needed (and the expectation that everyone else will assist Sweden). ${ }^{91}$ Also, the law on operational military support between Sweden and Finland conveys this impression of course, with respect to Finland most decisively in cases not amounting to an armed attack. ${ }^{92}$

\subsection{Doctrinal Views}

Ove Bring, Swedish professor emeritus and former legal adviser at the Ministry for Foreign Affairs, even writes that the Swedish unilateral 'declaration of solidarity' must be interpreted as meaning that Sweden fully accepts the solidarity clauses of the TEU and the TFEU respectively; Ove Bring includes both Article $42(7)$ in the TEU and Article 222 in the TFEU in his analysis. ${ }^{93}$ Ove Bring writes further that in relation to Norway and Iceland - who are included among the addressees of the Swedish 'declaration of solidarity' but who are not EU members - it is a matter of a politico/moral declaration of solidarity. ${ }^{94}$ However, in relation to the EU members Sweden confirms the existence of an international legal obligation, Ove Bring concludes. ${ }^{95}$

Since Finland considers that the mutual defence clause in Article 42(7) (which is of greatest interest here) is equally obliging for all member states, as we saw earlier, the interpretation of the Swedish stance suggested by Ove Bring would mean that Sweden and Finland are both legally bound under Article $42(7)$ in the TEU to assist one another in case of an armed attack by all the means in their power. This interpretation of the obligations for Sweden's part under Article 42(7) in its turn would bring to the fore the provision in Article 15:16, first sentence, of the Swedish Instrument of Government, saying that " $[\mathrm{t}]$ he Government [alone] may send Swedish armed forces to other countries or otherwise deploy such forces in order to fulfil an international obligation approved by the Riksdag." Here there would then be a constitutional legal

\footnotetext{
$90 \quad$ Cf. supra note 18 et seq.

$91 \quad C f$. supra note 56 . Ahlin, supra note 5 , p 34, is of the opinion that the Swedish reliance on NATO while not being a member is a legally insecure and politically impossible policy to keep up in the long run.

92 Regeringens proposition (government bill) 2019/20:110, supra note 10.

93 Bring, supra note 2, p. 84.

$94 \quad$ Ibid.

95 Ibid.
} 
basis for the government to send Swedish armed forces to Finland in case of an armed attack on Finland. According to this legal basis, there is no need for the government to ask for the approval by Parliament in every particular case.

If the Swedish obligations under Article 42(7) were interpreted in the way Ove Bring suggests, then arguably these international obligations would cover both the sending of Swedish armed forces to assist Finland in the case of situations below the threshold of armed conflict and in situations above this threshold. As we have seen, however, the Swedish government is of the opinion that in case of armed conflict the approval by Parliament would still always be necessary before the government may decide on the deployment of Swedish armed forces to assist Finland. This must imply that the Swedish government does not interpret Article 42(7) of the TEU as constituting a binding obligation on Sweden, and thus that the Swedish government's interpretation of Article $42(7)$ differs from the one of the Finnish government and, presumably, from the one suggested by Ove Bring.

\subsection{The Symbolism of Political Decision-Making}

If we would regard the TEU Article 42(7) as legally binding, as Finland does for instance, and we would then consider the different kinds of aid and assistance offered to France by the different member states of the EU in the wake of the terrorist attacks in Paris in 2015, most member states in fact providing no aid and assistance at all, it would seem as if the combination of a binding collective self-defence agreement on the one hand and on the other hand, firstly, political decision-making concerning what assistance should be provided among the parties to the binding agreement in the event of an armed attack on one of the parties, and, secondly, differing political decision-making among the members is not impossible or even hard to imagine.

If this is an example of the way in which a binding collective defence undertaking could be executed, then the Swedish emphasis on the necessity of Sweden being able to make "the necessary political decisions" before Sweden would act in collective self-defence together with another state in order to meet an armed attack - most immediately in a scenario involving Sweden and Finland - would seem a little superfluous, if not meaningless. ${ }^{96}$ At least the Swedish insistence on the necessity for Sweden of being able to make the necessary political decisions before acting militarily within the framework of a collective self-defence operation would not in principle make it impossible to enter into a binding collective defence treaty; even within the framework of a binding collective defence treaty Sweden would be able to make the necessary 
political decisions in order to arrive at whether it would provide any assistance and if wo what kind of assistance it would provide. The latter in its turn would be partly dependent on what different kinds of assistance that were included in the treaty arrangement. Obviously, the political decision-making condition did not prevent Sweden from entering into the non-binding 'deepened defence co-operation' with Finland arguably a non-binding collective defence pact. ${ }^{97}$

As we saw earlier, the terms of reference of the first of the two official commissions of inquiry investigating the constitutional legal conditions for Sweden's deepened defence co-operation with Finland, stated the task of the commission of inquiry thus:

[An official commission of inquiry] shall analyze the conditions under the Instrument of Government, provided that the necessary political decisions are made, for Sweden to act with military resources jointly with another state in order to meet an armed aggression against any of the states and in order to prevent violations of the territory of any of the states in peacetime and during war between foreign states. ${ }^{98}$

The commission of inquiry was not given the unconditional mandate to investigate "the conditions under the Instrument of Government for Sweden ... to act jointly with another state with military resources in order to meet an armed attack on any of the states ... ."99

Claiming that it would be impossible or at least unthinkable for Sweden to be party to a binding collective defence agreement containing mutual defence obligations is self-contradictory if one considers Article 42(7) of the TEU to be binding. ${ }^{100}$

If Article 42(7) of the TEU is not considered binding, however, then the Swedish position is still tenable. The only position that would seem logically impossible to take would be to simultaneously claim that Article 42(7) does entail a binding collective defence obligation and that it does not entail a binding collective defence obligation. Sweden, in contrast to Finland, thus maintains the position that Article 42(7) of the TEU does not entail a binding collective defence obligation.

\footnotetext{
$97 \quad$ Supra note 59.

98 Dir. 2015:111, supra note 39, p. 1, emphasis added.

99 Cf. Dir. 2015:111, supra note 39, p. 1.

$100 \quad$ Ibid., p. 2.
} 
If the Swedish government would want there to exist a binding mutual defence obligation laid down in an international treaty approved by the Riksdag (Parliament), as stated in Article 15:16 of the Instrument of Government, and enabling the government to decide on the sending of armed forces abroad for any purpose without having to seek the prior approval of parliament, then the Swedish government since 2009 could in principle invoke Article 42(7) of the TEU. Currently, Sweden does not seem so keen on the idea of being party to a binding collective defence clause, even if a mutual defence obligation would also benefit Sweden hypothetically, so Sweden claims that it is not and that it could not be party to a binding collective defence agreement.

If we discard the theoretical possibility that an absolute and unconditional "international obligation" was intended in Article 15:16 of the Swedish Instrument of Government, but instead that what was intended was an international obligation of a more conventional kind which includes a measure of discretion and freedom of choice on the part of the obliged state, then the collective defence clause in Article 42(7) of the TEU would fit very well under the label of "international obligation approved by the Riksdag" in Article 15:16 of the Instrument of Government.

If the Swedish government wishes to claim that the second sentence in the first paragraph of Article 42(7) of the TEU applies according to the Swedish interpretation and thus that Article 42(7) "does not entail any form of defence obligation for militarily non-aligned member states like Sweden", then the Swedish government is free to do so, in contrast it seems to what the Finnish government would claim although it too is a non-aligned member state of the EU. ${ }^{101}$ However, if the Swedish government would like to modify its position, for reasons of expediency or for any other reason, then it could interpret Article $42(7)$ as if the latter indeed entails a (collective) defence obligation although as also written in the text of the provision not absolutely and unconditionally prescribing any particular kind of action but merely obliging the parties to "aid and [assist] by all the means in their power."102

101 Regeringens proposition (government bill) 2007/o8:168, supra note 10, p. $25^{2}$.

102 Maybe this thought is akin to what Ove Bring proposes, namely that "[f]or Sweden the non-alignment is limiting to the extent we ourselves decide" (in Swedish, "[f]ör Sveriges vidkommande är alliansfriheten gränssättande i den utsträckning vi själva bestämmer”), O. Bring, supra note 2, p. 82 . 
Sweden could continue to consider itself militarily non-aligned, but still in some situations depending on the circumstances choose to abide by what it simultaneously could consider its obligation under Article 42(7) to aid and assist an attacked member state of the EU by all the means in Sweden's power, and by means that would be requested by the member state that Sweden would thus help including the sending of Swedish armed forces to the country in question or to some other country depending on where the collective self-defence would be supposed to take place. When the situation so required, the Swedish government, if, and only if, it so wished could then make the decision to aid and assist alone without involving Parliament, based on Article 15:16 of the Swedish Instrument of Government. 